Problems of Tribology

Website: http://tribology.khnu.km.ua/index.php/ProbTrib

E-mail: tribosenator@gmail.com

DOI: https://doi.org/10.31891/2079-1372-2021-101-3-48-55

\title{
Regression analysis of the influence of auger surface hardness on its wear during dehydration of solid waste in a garbage truck
}

\author{
O.V. Bereziuk ${ }^{1 *}$, V.I. Savulyak ${ }^{1}$, V.O. Kharzhevskyi ${ }^{2}$ \\ ${ }^{1}$ Vinnitsa National Technical University, Ukraine \\ ${ }^{2}$ Khmelnytskyi National University, Ukraine \\ *E-mail: berezyukoleg@i.ua
}

Received: 19 May 2021: Revised: 11 August: Accept: 17 September 2021

The article is dedicated to the study of the influence of the surface hardness of the auger on its wear during dehydration of solid waste in the garbage truck. Using the method of regression analysis, the logarithmic dependencies of auger wear depending on the hardness of its surface for different values of the friction path are determined. Graphical dependences of augur wear depending on the hardness of its surface for different values of the friction path are made up, and it confirms sufficient convergence of the obtained dependencies. Carried out additional regression analysis allowed to obtain the dependence of wear of the auger depending on the hardness of its surface and the friction path, which showed that during two weeks of operation and wear of the auger during dehydration of solid waste in the garbage truck increasing the surface hardness of the auger from $2310 \mathrm{MPa}$ to $10050 \mathrm{MPa}$ reducing the rate of growth of energy consumption of solid waste dehydration from $16.7 \%$ to $1.5 \%$, and, consequently, to reduce the cost of the process of their dehydration in the garbage truck. The graphical dependence of the reduction of energy consumption of dehydration of solid household waste due to the increase in the hardness of the auger surface during its two-week wear is presented. It was established the expediency of further research to determine the rational material of the auger and ways to increase its wear resistance.

Key words: wear, surface hardness, auger press, garbage truck, dehydration, solid waste, regression analysis.

\section{Introduction}

In mechanical engineering, one of the main tasks is to increase the wear resistance and reliability of machine parts [1, 2]. A promising technology for primary processing of municipal solid waste (MSW), aimed at reducing both the cost of transportation of solid waste and the negative impact on the environment is their dehydration, accompanied by pre-compaction and partial grinding, during loading into the garbage truck. Dehydration of solid waste in the garbage truck is performed using a conical screw, the surface of which due to the existing friction wears out intensively. This is due to the fact that solid waste contains, in particular, components such as metal, glass, ceramics, stones, bones, polymeric materials, which can be attributed to abrasive materials because they have different shapes, sizes and hardness, and the presence of moisture $39-92 \%$ by weight in MSW creates an aggressive corrosive environment. Therefore, the study of the influence of the hardness of the auger surface on its wear during dehydration of solid waste in the garbage truck is a topical task. Dehydration of solid waste in the garbage truck is performed using a conical auger, the surface of which due to the existing friction wears out intensively. This is due to the fact that solid waste contains, in particular, such components as metal, glass, ceramics, stones, bones, polymeric materials, which can be attributed to abrasive materials because they have different shapes, sizes and hardness, and the presence of moisture 39 - $92 \%$ by weight in solid wastes creates an aggressive corrosive environment. Therefore, the study of the influence of the hardness of the auger surface on its wear during dehydration of solid waste in the garbage truck is an urgent task. 


\section{Literary review}

The article [3] presents the results of experimental studies of wear resistance of different auger materials with different thermal and chemical-thermal treatment in a corrosive-abrasive environment on special friction machines that simulated the operating conditions of extruders in the processing of feed grain with saponite mineral impurities. The authors found that the wear resistance of materials in a corrosive-abrasive environment at elevated temperatures depends not only on the hardness of the friction surface, but also on its structure and phase composition and changes in the hardness gradient along the depth of the hardened layer. To ensure high wear resistance of extruders in the manufacture of animal compound feed with impurities of the mineral saponite, it is recommended to use for the manufacture of parts of the extrusion unit steel X12, hardened by nitro-hardening technology.

The author of [4] found that the intensity of abrasive wear of the screw surface of the auger, and wear resistance mainly depends on the hardness, surface roughness, the volume of abrasive particles involved in friction and the area of their contact with the surface

In the article [5], a mathematical model for calculating the wear rate of triboelements in a tribosystem operating in conditions of corrosion and abrasive wear was developed. The input factors were: active acidity, abrasiveness, roughness, load and sliding speed. Theoretically, the degree of influence of the above factors on the wear rate is established. It was found that abrasiveness is the most important factor, followed by the degree of decline - the level of active acidity and load.

A new design of the auger with a sectional elastic surface, which is designed to reduce the degree of damage to the grain material during its transportation is presented in the article [6]. The theoretical calculation of the interaction of the grain with the elastic section of the auger is carried out. A dynamic model has been developed to determine the influence of structural, kinematic and technological parameters of the elastic auger on the time and path of free movement of bulk material particles during their movement between sections, as well as to exclude the possibility of grain material interaction with the non-working surface of the auger working body.

In the article [7] it was determined that restoration of the auger requires surfacing or spraying a layer of a certain thickness on the end part of the coil of the auger, while the width of the restored layer is usually a few millimeters. An algorithm for selecting the optimal composite powder material for plasma spraying in order to increase the wear resistance of the working surfaces of machine parts, in particular the auger, is described. According to the authors, plasma spraying of composite powder materials will increase the durability of the auger by 2 - 3 times, which will reduce repair costs by tens of times.

In the article [8] the influence of geometrical parameters on productivity and design of the briquetting machine using the model of pressure based on the theory of piston flow is investigated. An analytical model that uses a pressure model was also developed based on Archard wear law to study the wear of augers of biomass briquetting machines. The developed model satisfactorily predicted the wear of the auger and showed that the greatest influence on it have the speed of rotation and the choice of material. The amount of wear increases exponentially to the end of the auger, where the pressure is the highest. Changing the design of the auger to select the optimal geometry and speed with the appropriate choice of material can increase the life of the auger and the productivity of the machine for briquetting biomass.

The work [9] is devoted to the analysis of the process of screw briquetting of plant materials into fuel and feed. Regularities of this process are the basis for determining the rational parameters of the working bodies. When designing briquette presses it is necessary to consider deformation of biomass taking into account change of physical and rheological properties at the moment of interaction with the auger mechanism

In the article [10] the wear of a twin-auger extruder of rigid PVC resins is investigated. The pressures around the cylinder when extruding two rigid PVC resins in a laboratory extruder with a diameter of $55 \mathrm{~mm}$ were measured and the forces acting on the auger core were determined. Numerical simulation of the flow was performed using the power parameters of the viscosity of the resins.

In the work [11] the process of pressing wood chips in auger machines was investigated. The processes occurring in different parts of the auger are established, formulas are defined that allow to calculate the loads acting on the auger coils, as well as to determine the power required for pressing. The specific energy consumption and the degree of heating of raw materials during pressing are determined.

The results of experimental studies of the process of solid dehydration based on the planning of the experiment by the Box-Wilson method are shown in the article [12]. Quadratic regression equations with the $1^{\text {st }}$ order interaction effects were obtained using rotatable central composite planning for such objective functions as humidity and density of pre-compacted and dehydrated MSW, maximum drive motor power, energy consumption of solid waste dehydration. This allowed to determine the optimal parameters of equipment for dehydration by the criterion of minimizing the energy consumption of the process (auger speed, the ratio of the radial gap between the auger and the body, and the ratio of the auger core diameter to the outer diameter of the auger on the last coil) for both mixed and "wet".

In the article [13] the improved mathematical model of work of the dehydration drive of MSW in the garbage truck is suggested that takes into account wear of the auger. It allowed to research numerically the dynamics of this drive during the start-up, and to define that with the increase of wear of the auger pressure of 
working liquid on the speed of the auger it is significantly reduced. The power regularities of change of the nominal values of pressures at the inlet of the hydraulic motor, angular speed and frequency of rotation of the auger from values of its wear are defined, the last of which describes detuning from optimum frequency of rotation of the auger in the course of its wear. It is established that the wear of the auger by $1000 \mu \mathrm{m}$ leads to an increase in the energy consumption of solid dehydration by $11.6 \%$, and, consequently, to an increase in the cost of the process of their dehydration in the garbage truck and accelerate the wear process.

\section{Purpose}

Researching the influence of auger surface hardness on its wear during dehydration of solid waste in a garbage truck.

\section{Methods}

Determination of paired dependencies of auger wear from the hardness of its surface was performed by regression analysis [14]. Regressions were determined on the basis of literalizing transformations, which allow to reduce the nonlinear dependence to the linear one. The coefficients of regression equations were determined by the method of least squares using the developed computer program "RegAnaliz", which is protected by a copyright registration certificate, and is described in the article [15].

The following dependencies were used to determine the energy consumption of solid dehydration taking into account the auger wear [13]:

$$
\begin{aligned}
& E=1504-15.92 w_{0}+0.3214 \rho_{0}-1.069 n(u)-2061\left(\Delta_{\text {aug }}+u\right) /\left(D_{\min }-2 u\right)- \\
& -1947\left(d_{\min }-2 u\right) /\left(D_{\min }-2 u\right)+9.118 \cdot 10^{-4} w_{0} \rho_{0}+0.002142 w_{0} n(u)+ \\
& +18.12 w_{0}\left(\Delta_{\text {aug }}+u\right) /\left(D_{\min }-2 u\right)-2.115 w_{0}\left(d_{\min }-2 u\right) /\left(D_{\min }-2 u\right)+4.392 \cdot 10^{-4} \rho_{0} n(u)- \\
& -2.005 \rho_{0}\left(\Delta_{\text {aug }}+u\right) /\left(D_{\min }-2 u\right)+0.3361 \rho_{0}\left(d_{\min }-2 u\right) /\left(D_{\min }-2 u\right)+ \\
& +0.09031 w_{0}^{2}-7.923 \cdot 10^{-4} \rho_{0}^{2}+0.008241 n(u)^{2}+104172\left[\left(\Delta_{\text {aug }}+u\right) /\left(D_{\min }-2 u\right)\right]^{2}+ \\
& +1318\left[\left(d_{\min }-2 u\right) /\left(D_{\min }-2 u\right)\right]^{2}[\mathrm{kWh} / \text { tons }]
\end{aligned}
$$

$$
n=52.43-1.276 \cdot 10^{-3} u^{1.5}[\mathrm{rpm}]
$$

where $E$ - is the energy consumption of solid waste dehydration, $\mathrm{kW} \cdot \mathrm{h} /$ tons;

$\rho_{0}-$ initial density of solid waste, $\mathrm{kg} / \mathrm{m}^{3}$;

$w_{0}$ - initial relative humidity of solid waste, $\%$;

$n$ - the nominal speed of the auger, rpm;

$u$ - auger wear, m;

$\Delta_{\text {aug }}$ - radial clearance between auger and housing, $\mathrm{m}$;

$d_{\text {min }}$ - outer diameter of the auger on the last coil, m;

$D_{\text {min }}$ is the diameter of the auger core on the last coil, m.

\section{Results}

The values of auger wear for different values of hardness of its surface and friction path are given in Table 1 [3].

As a result of regression analysis of the data in Table 1, is was determined the logarithmic dependencies of wear of the auger depending on the hardness of its surface for different values of the friction path:

$$
\begin{aligned}
& u_{\mathrm{s}=3000}=334-34.07 \ln H ; \\
& u_{\mathrm{s}=6000}=676.6-69.69 \ln H ; \\
& u_{\mathrm{s}=9000}=999.8-103 \ln H ; \\
& u_{\mathrm{s}=12000}=1295-132.7 \ln H,
\end{aligned}
$$

where $u$ - wear, $\mu \mathrm{m}$;

$H$ - hardness of auger surface, $\mathrm{MPa}$; 
$S-$ friction path, m.

Fig. 1 shows graphical dependences of auger wear depending on the hardness of its surface for different values of the friction path, made up using the dependences $(3-6)$, which confirmed the sufficient convergence of the obtained dependencies compared with the data in the Table 1

Table 1

Screw wear values for different values of surface hardness and friction path [3]

\begin{tabular}{|c|c|c|c|c|c|}
\hline \multirow{2}{*}{ № } & \multirow{2}{*}{ Surface hardness, MPa } & \multicolumn{4}{|c|}{ Wear, $\mu \mathrm{m}$ for friction path, $\mathrm{m}$} \\
\cline { 3 - 6 } & & 3000 & 6000 & 9000 & 12000 \\
\hline 1 & 2310 & 68 & 132 & 195 & 258 \\
\hline 2 & 5180 & 53 & 103 & 153 & 203 \\
\hline 3 & 6500 & 48 & 91 & 134 & 177 \\
\hline 4 & 6510 & 43 & 80 & 116 & 152 \\
\hline 5 & 6700 & 39 & 72 & 105 & 138 \\
\hline 6 & 10050 & 25 & 43 & 63 & 88 \\
\hline 7 & 5450 & 26 & 47 & 70 & 98 \\
\hline 8 & 7860 & 24 & 43 & 64 & 90 \\
\hline 9 & 8600 & 22 & 39 & 58 & 82 \\
\hline 10 & 6950 & 28 & 52 & 78 & 108 \\
\hline 11 & 8100 & 15 & 25 & 38 & 55 \\
\hline
\end{tabular}

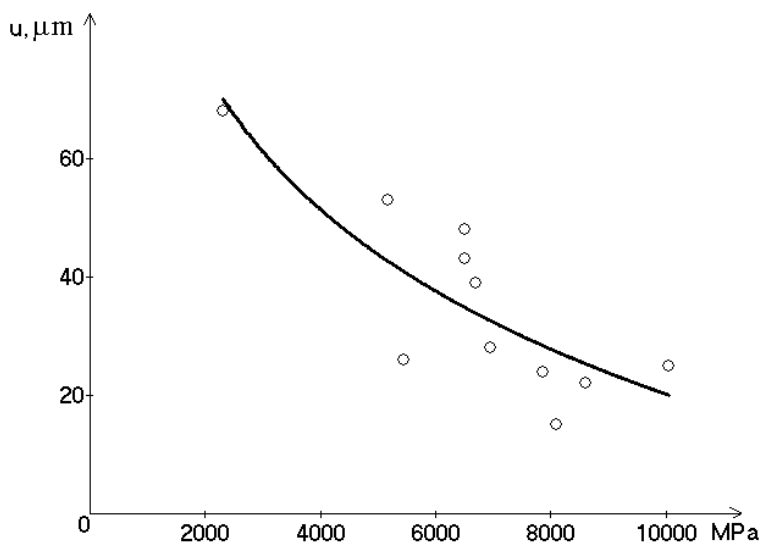

$\mathbf{a}$

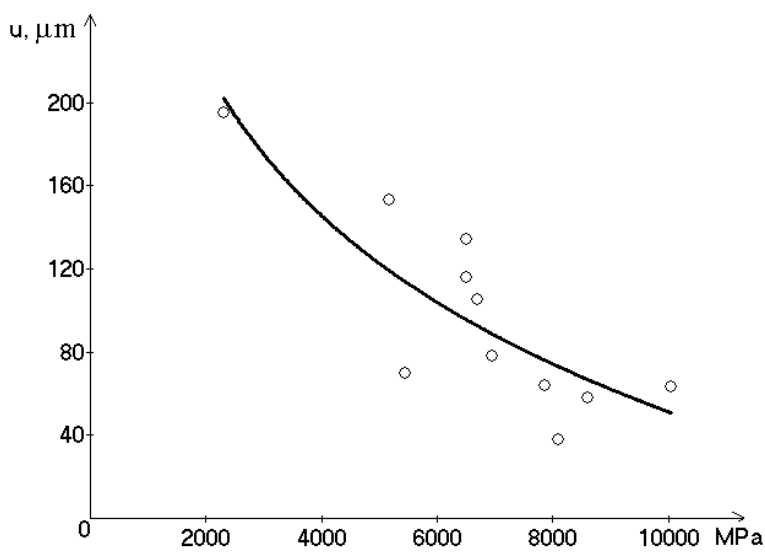

c

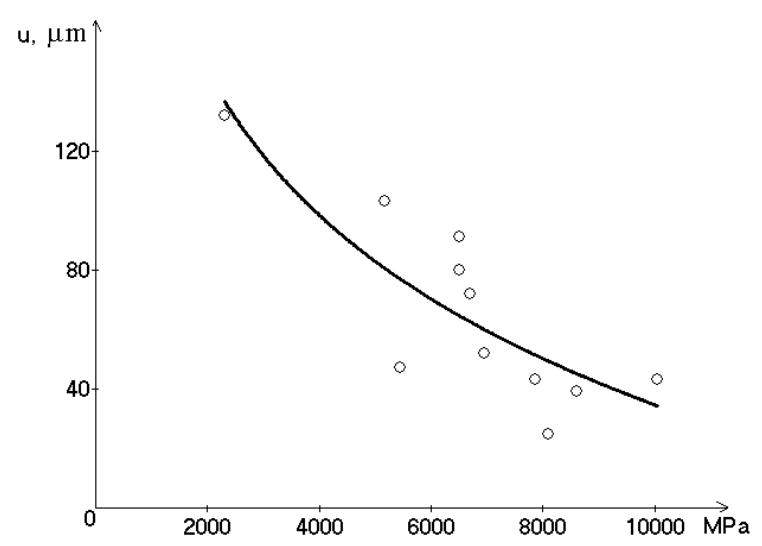

b

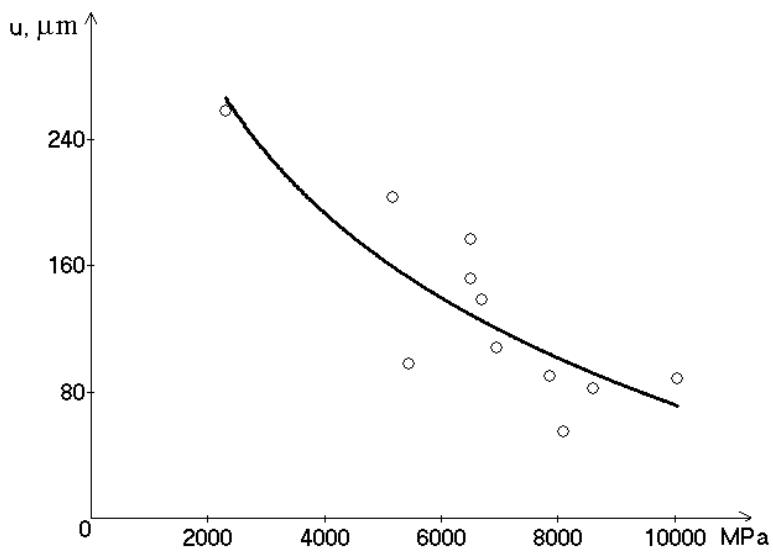

d

Fig.1. The wear of the auger depending on the hardness of its surface for different values of the friction path:

$$
\begin{gathered}
\mathrm{a}-s=3000 \mathrm{~m} \\
\mathrm{~b}-s=6000 \mathrm{~m} \\
\mathrm{c}-s=\mathbf{9 0 0 0} \mathrm{m} ; \\
\mathrm{d}-s=\mathbf{1 2 0 0 0 \mathrm { m }} \\
\text { actual } \circ, \text { theoretical }-
\end{gathered}
$$


Dependences $(3-6)$ for different values of the friction path can be written in general as follows:

$$
u=A(s)-B(s) \ln H,
$$

where $A(s), B(s)$ - regression coefficients that depend on the path of friction.

After the additional regression analysis, the regression coefficients which depend on the friction path can be described by power laws:

$$
\begin{aligned}
& A(s)=0.5796 s^{0.83}-112.8 \\
& B(s)=0.08049 s^{0.8}-14.71
\end{aligned}
$$

Table 2

The results of regression analysis of the dependence of the wear of the auger depending on the hardness of its surface for different values of the friction path

\begin{tabular}{|c|l|c|c|c|c|c|c|}
\hline \multirow{2}{*}{$№$} & \multirow{2}{*}{ Type of regression } & \multicolumn{5}{|c|}{ Correlation coefficient $R$ for paired regressions } \\
\cline { 3 - 8 } & & $u_{s=3000}=f(H)$ & $u_{s=6000}=f(H)$ & $u_{s=9000}=f(H)$ & $u_{s=12000}=f(H)$ & $A=f(s)$ & $B=f(s)$ \\
\hline 1 & $y=a+b x$ & 0.81439 & 0.82376 & 0.82898 & 0.83452 & 0.99945 & 0.99918 \\
\hline 2 & $y=1 /(a+b x)$ & 0.66421 & 0.65974 & 0.67435 & 0.68887 & 0.92263 & 0.92049 \\
\hline 3 & $y=a+b / x$ & 0.78654 & 0.79114 & 0.79630 & 0.80646 & 0.93981 & 0.94199 \\
\hline 4 & $y=x /(a+b x)$ & 0.81920 & 0.80115 & 0.81299 & 0.82996 & 0.75583 & 0.59710 \\
\hline 5 & $y=a b^{x}$ & 0.75553 & 0.76285 & 0.77229 & 0.78180 & 0.97494 & 0.97347 \\
\hline 6 & $y=a e^{b x}$ & 0.75553 & 0.76285 & 0.77229 & 0.78180 & 0.97494 & 0.97347 \\
\hline 7 & $y=a \cdot 10^{b x}$ & 0.75553 & 0.76285 & 0.77229 & 0.78180 & 0.97494 & 0.97347 \\
\hline 8 & $y=1 /\left(a+b e^{-x}\right)$ & 0.66421 & 0.65974 & 0.67435 & 0.68887 & 0.92263 & 0.92049 \\
\hline 9 & $y=a x^{b}$ & 0.73813 & 0.74002 & 0.74896 & 0.76165 & 0.99969 & 0.99950 \\
\hline 10 & $y=a+b \cdot \lg x$ & 0.82369 & 0.83066 & 0.83603 & 0.84439 & 0.98598 & 0.98706 \\
\hline 11 & $y=a+b \cdot \ln x$ & 0.82370 & 0.83067 & 0.83604 & 0.84440 & 0.98598 & 0.98706 \\
\hline 12 & $y=a /(b+x)$ & 0.66421 & 0.65974 & 0.67435 & 0.68887 & 0.92263 & 0.92049 \\
\hline 13 & $y=a x /(b+x)$ & 0.56134 & 0.54627 & 0.55756 & 0.57539 & 0.99987 & 0.99976 \\
\hline 14 & $y=a e^{b / x}$ & 0.68071 & 0.67801 & 0.68615 & 0.70077 & 0.98768 & 0.98864 \\
\hline 15 & $y=a \cdot 10^{b / x}$ & 0.68071 & 0.67801 & 0.68615 & 0.70077 & 0.98768 & 0.98864 \\
\hline 16 & $y=a+b x^{n}$ & 0.75806 & 0.76923 & 0.77404 & 0.77662 & 0.99998 & 0.99996 \\
\hline
\end{tabular}

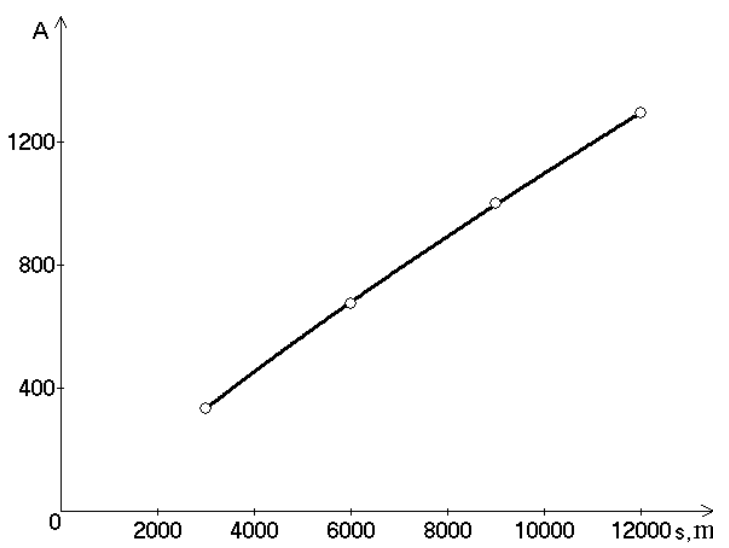

a

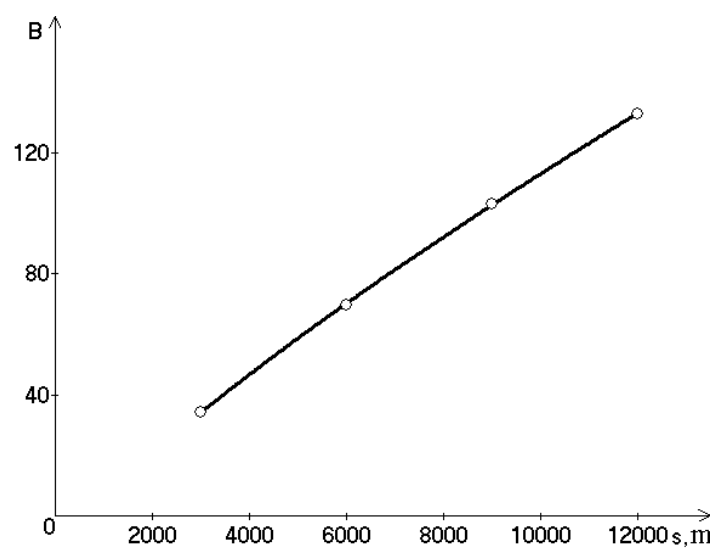

b

Fig. 2. Dependences of regression coefficients on the friction path $a-A=f(s) ; b-B=f(s)$; actual $\circ$, theoretical -

The results of the regression analysis are shown in Table 2, where the cells with the maximum values of the correlation coefficient $R$ for each of the paired regressions are marked in gray. Figure 2 shows the graphical 
dependences of the regression coefficients on the path of friction, constructed using the dependences $(8,9)$, which confirm the sufficient convergence of the obtained dependencies.

After substituting the laws $(8,9)$ into the dependence $(7)$, we obtain the law of wear of the auger depending on the hardness of its surface and the friction path:

$$
u=0.5796 s^{0.83}-112.8-\left(0.08049 s^{0.8}-14.71\right) \ln H .
$$

Fig. 3 shows a graphical dependence of the wear of the auger in the plane of the parameters of influence: the hardness of its surface and the friction path.

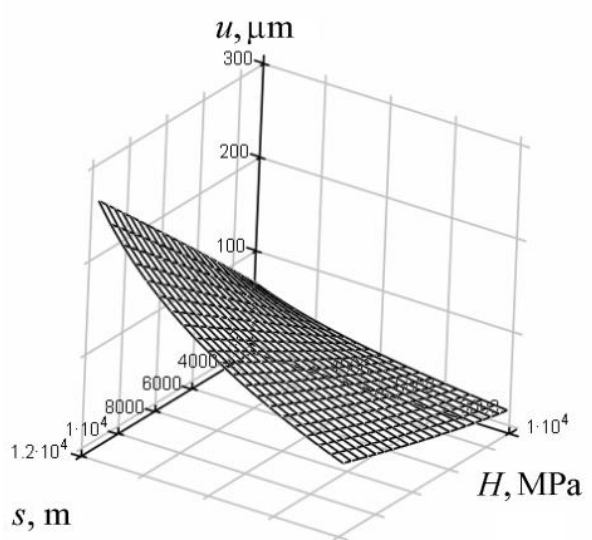

Fig. 3. The dependence of the wear of the auger $u$ in the plane of the parameters of influence: the hardness of its surface $H$ and the friction path $s$

Determine the path of friction for the surface of the auger dehydration of solid waste after its two-week operation:

$$
s=\frac{\pi d_{a v} n t_{c y c l e} K_{c y c l e} n_{c}}{26 \cdot 60}=\frac{3.14 \cdot 0.0775 \cdot 52.43 \cdot 855.6 \cdot 290 \cdot 28}{26 \cdot 60}=56850, \mathrm{~m}
$$

where $d_{a v}$ - the average diameter of the auger on the last coil, $\mathrm{m}$;

$t_{\text {cycle }}$ - the duration of the operating cycle of dehydration of one solid waste container, sec;

$K_{\text {cycle }}$ - annual number of working cycles of the garbage truck taking into account dehydration of solid waste, pcs;

$n_{c}$ - the number of solid waste containers loaded into the body of the garbage truck in one cycle, taking into account dehydration, pcs.

Figure 4 shows the graphical dependence of the influence of the hardness of the working surfaces of the auger of the mechanism of dehydration of solid waste on the energy consumption of the process $(S=56850 \mathrm{~m})$, made up using dependencies $(1,2,10)$.

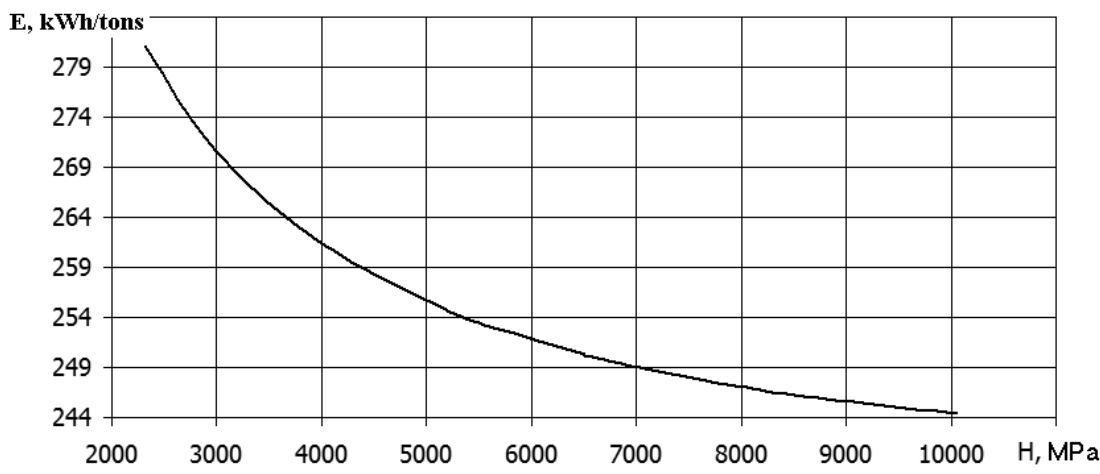

Fig. 4. The influence of increasing the hardness

of the working surface of the auger to reduce the growth rate of energy consumption of the dehydration process after its two-week operation and wear $(\mathrm{s}=56850 \mathrm{~m})$ 
Fig. 4 shows that after two weeks of operation and wear of the auger during dehydration of solid waste in the garbage truck the increase of the working surface hardness of the auger from $2310 \mathrm{MPa}$ to $10050 \mathrm{MPa}$ leads to a decrease in energy consumption of solid dehydration from $16.7 \%$ to $1.5 \%$, and therefore it reduces the cost of the process of dehydration of solid waste in the garbage truck. Thus, the determination of the rational material of the friction surfaces of the auger and the ways to increase its wear resistance require further research.

\section{Conclusions}

The logarithmic dependence of auger wear depending on the hardness of its surface for different values of the friction path are determined. Carrying out additional regression analysis allowed to obtain the dependence of wear of the auger depending on the hardness of its surface and the friction path, which showed that during two weeks of operation and wear of the auger during dehydration of solid waste in the garbage truck increasing the surface hardness of the auger from $2310 \mathrm{MPa}$ to $10050 \mathrm{MPa}$ reducing the rate of growth of energy consumption of solid waste dehydration from $16.7 \%$ to $1.5 \%$, and, consequently, it allowed to reduce the cost of the process of their dehydration in the garbage truck. Therefore, determining the rational material of the auger and ways to increase its wear resistance require further research.

\section{References}

1. Kindrachuk M.V., Labunets V.F., Pashechko M.I., Korbut E.V. (2009) Trybolohiya [Tribology]. Kyiv: Publishing of NAU "NAU-printing".

2. Dykha O.V. (2018) Rozrakhunkovo-eksperymentalni metody keruvannya protsesamy hranychnoho zmashchuvannya tekhnichnykh trybosystem: monohrafiya. [Computational and experimental methods for controlling the processes of maximum lubrication oftechnical tribosystems: a monograph.] Khmelnyts'kyi: KHNU

3. Kaplun V.H., Honchar V.A, Matviishin P.V (2013) Pidvyshchennya znosostiykosti shneka ta ekstrudera pry vyhotovlenni kormiv dlya tvaryn iz domishkamy mineralnoho saponitu. [Improving the wear resistance of the auger and extruder cylinder in the manufacture of animal feed with impurities of the mineral saponite]. Visnyk of Khmelnytsky National University, 5, 7-11.

4. Trifonov G.I. (2019) Abrazyvnyy znos i faktory, shcho vyznachayut' znosostiykist' robochykh poverkhon' shnekiv transportuyut' konveyeriv [Abrasive wear and factors determining the wear resistance of the working surfaces of the conveyor conveyor augers]. Nauka ta innovatsiyi - suchasni kontseptsiyi: Proceedings of the International Scientific Forum - Moscow: Infinity Publishing House, Vol. 1, 121-124.

5. Cymbal B.M. (2017) Pidvyshchennya znosostiykosti shnekovykh ekstruderiv dlya vyrobnytstva palyvnykh bryketiv u kyslotnykh ta luzhnykh seredovyshchakh [Increasing the wear resistance of auger extruders for the production of fuel briquettes in acidic and alkaline environments]: abstract dis. ... cand. tech. sciences: 05.02.04 - Friction and wear in machines, Kharkiv, 20.

6. Hevko R.B., Zalutskyi S.Z., Hladyo Y.B., Tkachenko I.G., Lyashuk O.L., Pavlova O.M., ... \& Dobizha N.V. (2019). Determination of interaction parameters and grain material flow motion on screw conveyor elastic section surface. INMATEH-Agricultural Engineering, 57(1).

7. Zhachkin S.Y., Trifonov G.I. (2017) Vplyv plazmovoho napylennya kompozytsiynykh poroshkovykh materialiv na znosostiykist' detaley mashyn [Influence of plasma spraying of composite powder materials on the wear resistance of machine parts]. Master's Journal, № 1, 30-36.

8. Orisaleye J.I., Ojolo S.J., Ajiboye J. S. (2019) Pressure build-up and wear analysis of tapered screw extruder biomass briquetting machines. Agricultural Engineering International: CIGR Journal, 21(1), 122-133.

9. Eremenko O.I., Vasilenkov V.E., Rudenko D.T. (2020) Doslidzhennya protsesu bryketuvannya biomasy shnekovym mekhanizmom [Investigation of the process of biomass briquetting by auger mechanism]. Inzheneriya pryrodokorystuvannya, 3 (17), 15-22.

10. Demirci A., Teke I., Polychronopoulos N. D., Vlachopoulos J. (2021) The Role of Calender Gap in Barrel and Screw Wear in Counterrotating Twin Screw Extruders. Polymers, 13(7), 990.

11. Tataryants M.C., Zavynskyy C.S., Troshyn A.D. (2015). Rozrobka metodyky rozrakhunku navantazhen' na shnek i enerhovytrat shnekovykh presiv [Development of a method for calculating auger loads and energy consumption of auger presses]. ScienceRise, 6 (2), 80-84.

12. Berezyuk O.V. (2018) Eksperymental'ne doslidzhennya protsesiv znevodnennya tverdykh pobutovykh vidkhodiv shnekovym presom [Experimental study of solid waste dehydration processes by auger press]. Visnyk Vinnyts'koho politekhnichnoho instytutu, № 5, 18-2413.

13. Bereziuk O.V., Savulyak V.I., Kharzhevskyi V.O. (2021) The influence of auger wear on the parameters of the dehydration process of solid waste in the garbage truck. Problems of Tribology, No 26(2/100), 79-86.

14. Chatterjee S., Hadi A.S. (2015) Regression analysis by example. John Wiley \& Sons.

15. Berezyuk O.V. (2015) Opredeleniye regressii koeffitsiyenta uplotneniya tverdykh bytovykh otkhodov ot vysoty poligona na osnove komp'yuternoy programmy "RegAnaliz". [Determination of the regression of the coefficient of compaction of municipal solid waste from the height of the landfill based on the computer program "RegAnaliz". ] Avtomatizirovannyye tekhnologii i proizvodstva, 2 (8), 43-45. 
Березюк О.В., Савуляк В.І., Харжевський В.О. Регресійний аналіз впливу твердості поверхні шнека на його знос під час зневоднення твердих побутових відходів у сміттєвозі.

Стаття присвячена дослідженню впливу твердості поверхні шнека на його знос під час зневоднення твердих побутових відходів у сміттєвозі. За допомогою використання методу регресійного аналізу визначено логарифмічні закономірності зносу шнека залежно від твердості його поверхні для різних значень шляху тертя. Побудовано графічні залежності зносу шнека залежно від твердості його поверхні для різних значень шляху тертя, що підтверджують достатню збіжність отриманих закономірностей. Проведення додаткового регресійного аналізу дозволило отримати закономірність зносу шнека залежно від твердості його поверхні та шляху тертя, за допомогою якої встановлено, що при двотижневій експлуатації та зношуванні шнека під час зневоднення твердих побутових відходів у сміттєвозі збільшення твердості поверхні шнека з 2310 МПа до 10050 МПа призводить до зниження темпів зростання енергоємності зневоднення твердих побутових відходів з $16,7 \%$ до 1,5\%, а, отже, і до здешевлення процесу їхнього зневоднення у сміттєвозі. Представлена графічна залежність зниження енергоємності зневоднення твердих побутових відходів внаслідок збільшення твердості поверхні шнека при його двотижневому зношуванні. Виявлено доцільність проведення подальших досліджень 3 визначення раціонального матеріалу шнека та шляхів підвищення його зносостійкості.

Ключові слова: знос, твердість поверхні, шнековий прес, сміттєвоз, зневоднення, тверді побутові відходи, регресійний аналіз. 